\title{
DEVELOPING EVIDENCE-BASED TEACHING PRACTICE
}

\author{
David Woodward, Shannon Booth, Sarah Redfearn, Elise Allen, \\ Don Samarasinghe and Alexa Forbes
}

\section{INTRODUCTION}

A small group of Graduate Diploma in Tertiary Education (Level 7) (GDTE) students and recent graduates, representing both the taught, Recognition of Prior Learning (RPL) and Independent Learning Pathway (ILP) programmes at Otago Polytechnic, collaborated as a Community of Practice (CoP) to write this research article.

The catalyst for this original research was a 2018 Capable NZ professional practice symposium discussion which presented examples of teaching philosophy statements and the process of preparing them (Woodward et al., 20 I 8). The audience was introduced to the use of metaphor and established frameworks, such as those developed by Chism (1998) and Schönwetter et al. (2002), for structuring teaching philosophy statements. "Developing a Teaching Philosophy for a Teaching Credential: Enablers, Challenges and Use of Metaphor" was presented at the 2019 Praxis Symposium (Woodward et al., 2019a) and later published in Scope (Woodward et al., 2019b).

The current research aims to preserve the use of the CoP as a powerful resource that can determine key theories and models that inform pedagogical practice. This research explores the models and theories that underpin the teaching practices examined; what drew the practitioners to particular models and theories; and how those theories link to teaching practice in the teachers' own areas of specialisation.

Unbeknown to us at the onset of this research, a major disruption to teaching practice was just around the corner. When the Covid-1 9 lockdown occurred, all teaching was moved to an online forum. Coping with this event was to prove a major challenge for both teachers and learners.

Several themes and common theoretical underpinnings emerged from the study. It is acknowledged that the participants were self-selected and were already working in CoPs, so are not necessarily representative.

\section{KEY MODELS AND THEORIES WHICH HELPTO INFORMTEACHING PRACTICE}

All participants (Shannon, Sarah, Elise, Don, Alexa) have practices grounded in constructivist theory, where learners construct knowledge based on experience and reflection. Humanism, proximal development and critical reflection also commonly feature in their practices. All the participants found that knowledge construction happened most efficiently in social settings where experiences, reflection and critical analysis could be shared with others and provide foundations for new learning. Biculturalism and Māori models were also consistent themes, with the concepts of ako (to teach and to learn) and tuakana/teina (relationship; older expert guides a younger novice) informing practice.

\section{Humanism and Māori models}

Shannon, working in the areas of physical education, health and parenting education, bases her practice in humanist theories. Fundamental to her personal views on teaching and learning is that she values her class members first as 
human beings and then as learners. This aligns with humanist theory and underpins much of what she does in an educational setting. The goal of humanistic education is to contribute to the development of energetic, positive, selfrespecting, caring human beings who can meet all challenges encountered (Chand, 2017). Humanism emphasises the importance of the inner world of the learner and places the individual's thoughts, feelings and emotions at the forefront of all human development. Humanistic education is therefore interested in educating the whole person, including their intellectual and emotional dimensions.

Shannon was also influenced by Te Whare Tapa Whā, a Māori model of health developed by Mason Durie in the early 1980s, that considers the whole person and their interrelationships. The model utilises an image of a strong, stable four-sided wharenui (Figure 3), where each of the four walls represents an equally valuable interrelated dimension of a person's overall wellbeing (Durie, 1998). The four dimensions are:

- Taha Tinana (physical wellbeing)

- Taha Wairua (spiritual wellbeing)

- Taha Hinengaro (mental/emotional wellbeing)

- Taha Whānau (social wellbeing).

Should one of the four walls or dimensions be missing or in some way damaged, a person may become unbalanced and subsequently unwell. Thus, for someone to have total wellbeing, all four areas of their wellbeing need to be in balance.

The fluidity and reciprocity of the Māori concepts of ako and tuakana-teina relational learning also resonate strongly with Alexa. For her, these concepts inform a bicultural approach that considers Te Whare Tapa Whā (Ministry of Health, 20 I I) and its extended Whare Taha Rima frameworks (20I I.) Te Whare Tapa Rima adds the taha whenua (symbolised by the Ātea) as a safe learning environment to Durie's Taha Whā model. Alexa uses these approaches to include mātauranga Māori as foundational. Alexa works on change-focused courses, the Bachelor of Leadership for Change and Graduate Diplomas in Sustainable Practice and Professional Practice. She adopts Appreciative Inquiry methods (Cooperrider \& Whitney, 2005) to build on individuals' strengths, rather than trying to fix problems. These frameworks are further theoretically unpinned by the work of Jarvis (2010) and by Blaschke's (2012) heutagogy. Learner-designed learning is key to this broad foundation and positions the learner at the centre of the learning process.

Alexa's guiding concept is the relational connection of all things. This could be pictured as mycelium - the fungi that connects trees and plants, providing the foundation for forests or bush. The mycelium recycles all nutrients and enables plants to communicate and support each other. Her underpinning mesh of frameworks, and the way they work together, is rounded out through humanist theories and the power of critical reflection.

\section{Constructivism}

Sarah, teaching in occupational therapy, is informed by constructivism theory, the approach set out in Knowles et al. (1998) and Kolb's (1984) experiential learning

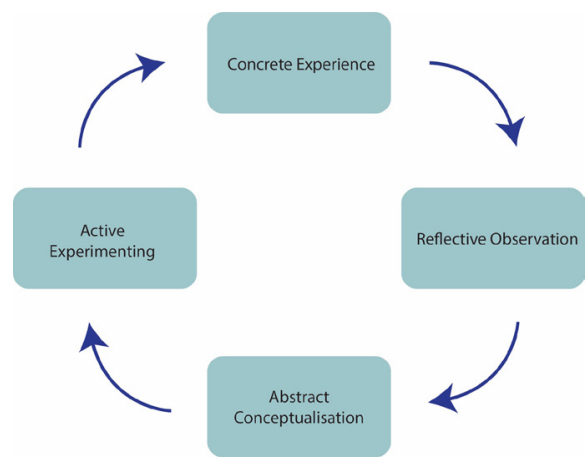

Figure I: Kolb's Experiential Learning Cycle (created by Elise Allen, 2020). 
cycle for reflective learning (Figure I). Don, teaching construction technology, has a practice similarly informed by constructivism, including experiential learning theory (Beard \& Wilson, 20I5; Brookfield, 1995; Moon, 2004; Thorpe, 2000).

Shannon's practice is also based in constructivism and she shares the overall philosophy that learning is an active, constructive process, where students construct their understanding and knowledge of the world based on their own unique experiences and by reflecting on those experiences. Learners build on their prior knowledge by comparing new ideas to the ones they already have, and learn through the similarities and differences they find (Bruner, 1966).

Constructivism therefore embraces the student as an active participant in the learning process, and the teacher's role moves towards that of a facilitator - encouraging learners to question, challenge and formulate their own ideas, opinions and conclusions through student interaction, discussion, collaboration, problem-solving and experiential learning activities. This all happens most effectively in groups, specifically communities of practice.

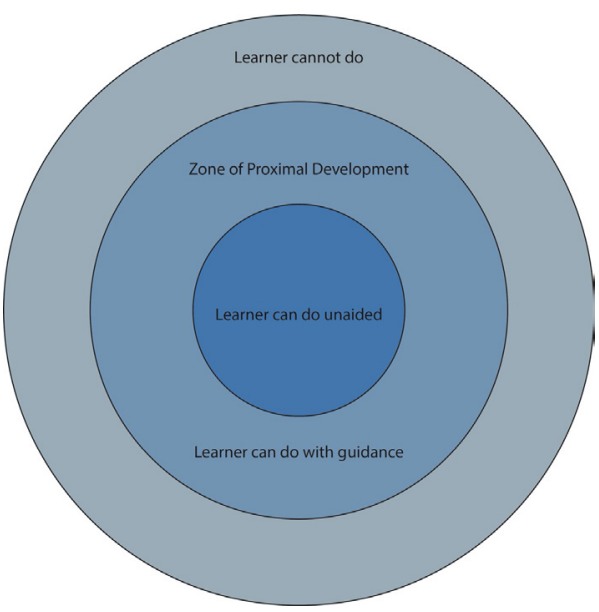

Figure 2.Vygotsky's Zone of Proximal Development (created by Elise Allen, 2020).
Elise, teaching in information technology, uses Vygotsky's (1978) social constructivism theory, allowing learning to come from learners via discussion and peer problemsolving. Student discussion becomes the focus of generating knowledge and ideas. ForVygotsky, the role of the teacher also includes prompting and coaxing learners into their "Zone of Proximal Development" (ZPD) (Figure 2), which can also be achieved by working with peers with differing levels of skill or knowledge. Pushing them into the ZPD can help learners to solve problems at a higher level than they would otherwise be capable of.

This theory can be used in conjunction with Kolb's (20I5) experiential learning cycle, whereby learners iterate through cycles of active experimentation, concrete experience, reflective observation and abstract conceptualisation. With both theories, learning is active and reflective, involving doing and discussing rather than the traditional, passive model of assimilating and regurgitating passed-on knowledge from a single authoritative source.

For Alexa, Vygotsky's (1978) ZPD underpins the CoP established across all the courses she works in. By giving learners practice in talking with others about their projects, they identify the framework for their own critical thinking. In the process, they become clearer and more capable of critical analysis of their own work and that of others. This supports community-building and builds confidence in taking work to a wider audience or platform.

Alexa facilitates learners almost entirely online, which poses certain challenges for her constructivist/postconstructivist approach where learners work to build reality together. However, she finds Vygotsky's theory lends itself to online learning as long as new protocols, such as specific design for the online environment, are introduced. Humanism and experiential learning theory encourage learners to connect with their values and recognise the formative culture and experiences within. Bill Reed's "three lines of work" (20I4) and "law of three" (20I6) provide simple frameworks that support learners to work simultaneously on self, on a CoP and on taking their work, through scaffolding, into the world. Reed's three lines of work shows three nested circles - self, community, world 
- that work concurrently in a spiral as a place to progress learning. The law of three offers a critical thinking framework. Reflection is a key learning tool for Alexa, and her practice is underpinned by Jennifer Moon's practical handbook of reflective and experiential learning (2004).

Don's practice, too, considers social constructivism theory, which holds that learning through social activities help learners to clarify ideas, gain skills and develop better understanding (Bonner et al., 20 I7). This is something that Don practices in his teaching. He engages his students with social and community activities, such as construction expos, to increase student engagement and effectiveness of learning (Samarasinghe et al., 2019). Don is also informed by the ARCS Model of Motivation which includes attention, relevance, confidence and satisfaction (Byram \& Dube, 2008).

\section{Social cognitive theory}

Don adds social cognitive theory to his practice, using observation (construction site visits), imitation (being a role model to learners) and modelling (practicing with building models in class) (Bonner et al., 2017; Camicia, 2017; Moon, 2004).

\section{WHAT DREW YOU TO THESE MODELS/THEORIES INTHE FIRST PLACE?}

Shannon was introduced to Durie's Te Whare Tapa Whā model in 200 I, while studying a paper at Otago University that analysed the newly released New Zealand Physical Education Curriculum document (Ministry of Education, 1999). This document was underpinned by the concept of hauora or 'total wellbeing.' In traditional Western culture, people are often seen as healthy, functioning individuals if they have their physical health and avoid disease and injury. However, Te Whare Tapa Whā encouraged Shannon to think about the overall wellbeing of a person. While the model acknowledges that physical health is indeed an important aspect of one's wellbeing, elements such as mental and emotional health, spiritual wellbeing and the social connections one enjoys through family and community support are equally important in determining wellness.

This approach opened Shannon's eyes to a new, more holistic way of looking at health and wellbeing, and of looking at education too.

It really resonated with me, because when I applied this to an educational setting, it highlighted the importance of how the bigger picture affects someone's ability to engage in the learning process. For example, factors such as family break-ups, self-esteem issues, having a roof over your head, food on the table, social connection with family and friends, a general sense of purpose - anything that impacts any of the four walls of a person's wellbeing - is going to affect the ability to learn, share, grow, live their life to the full and develop to their potential, be it in a classroom setting or in life in general. As an educator, I saw how crucial it was to build relationships and learn about the lives of those I was going to teach, in order to connect with them and attend to all four dimensions of their wellbeing, if I really wanted to give them every opportunity to learn and develop to their potential.

By contrast, Sarah was drawn to the writings of Knowles et al. (1998) on adult education, which echo many of her own experiences and observations. Knowles draws on theoretical approaches Sarah is familiar with and has used in a clinical context. Underpinning Knowles's work is the belief that learning is a developmental and creative process. For a learning environment to be effective, the learner needs the opportunity to link previous experience to new knowledge, play with ideas and concepts and ultimately contribute to their knowledge of self and self-actualisation (Maslow, 1954).

Sarah found Kolb's (1984) experiential learning cycle to be a simple reflective tool that she has used in developing her own clinical practice over the years: "I really relate to it because it uses a real, concrete experience as a starting point." She has since found that students also find the model useful to help them reflect on their experiences during fieldwork. 
Don did not attend pre-school; he experienced the primary learning and teaching environment in his mother's classroom, observing from age four. Sometimes he sat down with students and participated in class activities facilitated by his mother. He observed how his mother and her students behaved. He started to imagine that one day he would be a student. Maybe one day he would even be a teacher; he found it fun to be surrounded by many students and teachers. He experienced the class environment, staff meetings, staff activities and sports events at his mother's school. As a result, his passion for education was enhanced. On reflection, he felt the reason why he loved education was due to his mother's influence.

Don has been promoting learning through experience over the past ten years. He did not know that his teaching practices were in fact based in experiential learning theory until he undertook his GDTE. Throughout the process, he recognised the connections between his practice and learning and teaching theories. As he studied, he found that constructivism, social constructivism and social cognitive theories were closely aligned with his intuitive teaching practice. In recent years, he has seen that learner engagement and motivation significantly increases when students learn through experiences and social activities (Samarasinghe et al., 2019).

Elise observed that students were struggling to apply their technical knowledge outside of a lab-work context. Students learn technical skills by solving small problems and starting over again and again with progressively harder, but still small, problems. In the real world those same skills are more often used to contribute to a larger body of work - often in a team, and in the context of an ongoing project made up of smaller problems, rather than the small, stand-alone tasks required in the classroom. In the IT industry, people are often called upon to combine their existing knowledge in new ways to solve novel problems. This takes a lot of practice, so the more experienced practitioners are highly valued. Elise asks: Why does the experience of this way of working not start on day one of learning? We gain on-the-job experience by making mistakes and reflecting on them, and by working with people more experienced than ourselves. If we model the process of on-the-job learning, such as 'work-based' learning in the classroom, then learners can start gaining work experience from the day they start studying.

Alexa has recently explored the theoretical underpinnings of her learning and teaching approach through her GDTE. Prior to this, her approach was that modelled by the facilitators of a Graduate Diploma Sustainable Practice which she undertook in 2012 - 38 years after her first foray into tertiary education.

The experience of teaching and learning in 2012 was utterly and entirely different from that which I experienced in 1980/81. The pedagogy was unusual and wonderful in its inclusivity of the whole person and the idea of community scaffolding to support learners. I was struck by how much I learned when it appeared that little was taught and by how frameworks could hold complex issues and encourage positivity rather than overwhelm.

This introduced her to the concept of learning about learning and to the power of reflection, which she explored through writing a blog. Like Don, it was not until Alexa began the GDTE journey that she began to make the connections between her intuitive teaching practice and theory.

\section{HOW DO THESE MODELS AND THEORIES LINK TO TEACHING PRACTICE?}

Using a Māori model of health, Shannon demonstrates how she applied Te Whare Tapa Whā in the context of teaching antenatal classes for expecting parents (Figure 3). The examples show how she catered to all four dimensions of her class participants' wellbeing.

By contrast, Don believes that experiential learning, combined with reflective practice, is the most appropriate way to develop effective curriculum for his learners. Following Brookfield's (1995) four-lens reflective model, Don has considered his own and his learners' autobiography, educational literature and his learners' and colleagues' views, to develop his framework of teaching practice. His experiential learning practice is based on the model introduced by Roberts (2006), combined with the pedagogical model of critically reflective practice introduced by Kamardeen (2015), to ensure that his teaching is continually improving and delivers an effective curriculum for learners (Samarasinghe, 2019). 


\section{Taha Tinana (Physical)}

- Providing nutritious kai.

- Providing comfortable seating options, Swiss balls, and bean bags to use.

- Air conditioning for room temperature.

- Covering specific topics such as nutrition for pregnancy and breastfeeding, exercise during pregnancy and dealing with pregnancy discomforts.

\section{Taha Hinengaro}

\section{(Mental \& Emotional)}

- To share our feelings with peers and partners about how we feel about certain topics/issues surrounding pregnancy, birth, and parenting.

- Be a support person and sounding board for others going through similar situations.

- To feel supported and empowered to make decisions that sit well with our own beliefs and intuition.

\section{Taha Wairua (Spiritual)}

- Providing opportunities to explore various cultural traditions surrounding pregnancy, birth, and parenting.

- Providing opportunities to explore our own feelings, opinions, possible anxieties, and beliefs about what we want for our own birth and parenting journey.

- Spending time looking at our current relationships and how we will adapt to our new lives as parents reflecting on what kind of parent and partner we want to be.

\section{Taha Whānau (Social)}

- Opportunity to meet other expectant parents at a similar stage in their lives.

- Develop a sense of belonging and support in a group of parents who are sharing similar experiences at this time of their lives.

- Create a support network after the baby arrives.

- Establish an online Facebook group community for all parents in a class to connect.

- Arrange a reunion once all the babies have been born and initiate regular 'coffee catch ups' for the group. 
Ninety percent of Don's students come from overseas, which provides challenges in conducting class discussions in a New Zealand context. For example, international students are often unable to understand how to apply assessment questions in a case study context. As a solution, Don often matches international students with domestic students, enabling them to learn about issues like the Treaty of Waitangi and the Resource Management Act from experienced domestic students. Another challenge is that many international students come from passive learning environments where assessment is based on examinations rather than learner-centred assessments, such as case study presentations. Don approaches this issue, following Elen et al. (2007), by discussing with students the difference between their former passive learning style and the active learning style that suits the learner-centred class environment in New Zealand (Nistor \& Samarasinghe, 2019).

Likewise, Sarah used Knowles's et al. (1998) and Kolb's (1984) experiential learning theories to organise information and practice for students before they went on an 8-week clinical fieldwork placement.

My hope is to bridge the gap between theory and practice by using class time to teach not only content, but provide space to practice reflection and communication skills. For example, one week we have the topic of inpatient assessment. During the full class session, we discuss different types of assessment, why and how they are important to the occupational therapy process and the theory that connects with this. I am careful to give clinical examples that they will discover when they are on placement and relate it to the assessment for both this course and their fieldwork placement at the end of the year.

For Sarah, the tutorial is more experiential than the full class session, using artwork to develop observational skills, improve students' ability to interpret what they see and then articulate it. At the end of the session they are asked to carry out a practice observation assessment at home and bring it to the workshop. Students peer review each other's assessments using a check list and give feedback to each other. They are then asked to fill out a structured reflection on their own performance, using an adapted version of the model in Rolfe et al. (200 I).

The Kolb experiential cycle is completed by providing a concrete experience (carrying out the assessment tool), providing learners with the opportunity for verbal and written reflection on their experience, allowing time for them to think about their own development in relation to this skill and then providing another opportunity to practice. This cycle repeats each week, coming back to and building on essential transferable skills needed in clinical practice, including giving and receiving feedback and using reflection to take responsibility for their own learning.

For her part, Elise uses 'curated' social constructivism (Vygotsky, 1978), combined with experiential learning (Kolb, 20I5), with learners working in teams to produce an artefact that has been designed and 'curated' by the teacher to promote specific learning within the team. The learning itself comes from within the team, not from the teacher. The team discussion becomes the focus of generating knowledge and ideas. The role of the teacher ties in with Elise's teaching philosophy (Woodward et al., 20 I9b), which utilises the metaphor of a coach, prompting and coaxing rather than imparting knowledge. The coach designs the training session and the learners follow it, with guidance, to develop the relevant skills themselves. In this case, the project or artefact is chosen to make best use of the Zone of Proximal Development (ZPD) (Vygotsky, 1978), where help from teammates, plus coaching from teachers, pushes learners outside their comfort zone to solve problems at a higher level than they would normally be capable of. This kind of learning echoes the way in which, in the IT workplace, teamwork is used to generate ideas and solve problems that an individual might not be able to solve on their own.

By contrast, many of Alexa's learners are on independent learning pathway, with interaction through classes and one-to-one sessions held in virtual Zoom rooms. This makes establishing and working in a ZPD a little trickier than in a face-to-face taught programme. This challenge has required Alexa to engage in deep consideration of how to create spaces that support a social constructivist, humanist learning environment when people are physically separated but encouraged to bring their whole selves as they are. Alexa manages and mitigates the challenges by ensuring Zoom meetings are held regularly, both as a cohort and individually, and carefully structured 
to enable collective, ako-based learning within a CoP. Learners are encouraged to share their learning journeys, often breaking into small groups to discuss aspects of projects, and to critically examine each other's and their own work. These discussions are always rich, inclusive and deep, and the format serves to create zones of proximal development, encourage critical thinking and self-reflection and build from learners' strengths while creating opportunities to test and create ideas.

Tools such as the "world café" method (Brown, 2005) translate well to the online environment and ensure that even the quietest voices are heard. Alexa seeks to develop biculturalism through encouraging the exploration of axiology without judgement - Why do you think that? Does that thinking come from your place of cultural knowledge or other values? As a CoP, participants are encouraged to reflect on and acknowledge their individual privileges and biases.

\section{DISCUSSION}

Constructivism theory, including the use of experiential learning (Knowles et al., 1998; Kolb, 2015) and scaffolding (Brunner, 1966), and social constructivism, using Vygotsky's (1978) zone of proximal development, are the key theories that inform these teaching practitioners. Humanism theory, supported by Te Whare Tapa Whā (Durie, 1998), informed teachers of health and the online Leadership for Change course. Social cognitive theory informed teaching in construction technology, using observation, imitation and modelling (Bonner et al., 2017). Each teacher was drawn to pedagogical theories and models depending on the 'fit' with their individual specialist areas. For example, Sarah was drawn to andragogy and the experiential learning cycle because it could be applied to clinical practice learners in occupational therapy.

During the Covid-19 lockdown, teaching practice pivoted significantly to an online environment. However, resilient pedagogical frameworks including constructivism were still employed, using reflective practice and interactive online discussions where learners were actively engaged through digital platforms. Social constructivism was employed by dividing learners into groups where they could teach and learn from each other, as was humanism, where learners suffering from the challenges of disruption and job loss had their personal wellbeing considered. The use of these pedagogical theories continued for work-based learners on the independent learning pathway, where the impact on learning was minimal because these learners were already working in this online space.

Our CoP practitioners believe teaching practice needs to be flexible, given the diversity of learners and the diversity of learning environments. The disruptive Covid-19 lockdown period tested the resilience of these practices and allowed new skills to develop.

For example, Elise, 'coaching' in a 'curated' work-based, experiential learning environment, found online delivery more challenging, but the use of collaborative group activities, such as whiteboard, allowed students to make mistakes but still achieve. Working remotely was a highly valued learning experience for IT students. For his part, Don used a class notebook; students made short presentations and gave continuous formative and summative feedback which confirmed the effectiveness of synchronous learning. Sarah confirmed that the quality of assessments was high during lockdown; the challenge was to provide concrete experience and treat students as adults. Sarah indicated that online facilitation worked well if she kept to the Knowles principles and created the expectation that learners would arrive at online sessions prepared.

Shannon used a wide range of physical, mental, emotional, social and spiritual practices to cater for the total wellbeing of her learners. During lockdown she built on previously established relationships and, as a reflective practitioner, sought regular feedback to maintain connections. Alexa, working in an online, independent learning pathway CoP, had regular group and individual meetings, breaking students into groups and using world café (Brown, 2005). She pushed students out of their comfort zone to undertake critical self-reflection, using a heutagogical, akobased approach to develop transferable skills for learners, rather than train for a job. 
In conclusion, our teaching CoP identified a range of evidence-based pedagogy. Teachers employed a constructivist approach, where learners construct knowledge based on experience and reflection. Learners are scaffolded in their learning, in a social constructivist, contextualised environment, and are eventually pushed out of their comfort zone into the zone of proximal development (Vygotsky, 1978) - all the while supported in an inclusive, humanistic, bicultural, Te Whare Tapa Whā learning environment, enabling learners to move towards selfactualisation (Maslow, 1943).

Contact details: david.woodward@op.ac.nz

Beard, C., \& Wilson, J. P. (20I5). Experiential learning. London, UK: Kogan Page.

Blaschke, L. M. (2012). Heutagogy and lifelong learning: A review of heutagogical practice and self-determined learning. The International Review of Research in Open and Distributed Learning, 13(1), 56-71. https://doi.org/ / 0.19173/irrodl.v13il . 1076

Bonner, S. M., Somers, J.A., Rivera, G.J., \& Keiler, L. S. (20।7). Effects of student-facilitated learning on instructional facilitators. Instructional Science: An International Journal of the Learning Sciences, 45(4), 4I7-438.

Booth, S. A. C. (20।8). Graduate Diploma in Tertiary Education Portfolio [Unpublished manuscript]. Otago Polytechnic.

Brookfield, S. (1995). Becoming a critically reflective teacher. San Francisco, CA: Jossey-Bass.

Brown, J. (2005). The world café. Shaping our futures through conversations that matter. San Francisco, CA: Berrett-Koehler.

Bruner, J. (1966). Toward a theory of instruction. Cambridge, MA: Belknap Press of Harvard University.

Byram, R., \& Dube, H. (2008). Planning for success. New York, NY: Continuum International Publishing Group.

Camicia, S. P. (2017). Critical democratic education and LGBTQ-inclusive curriculum. New York, NY: Routledge.

Chand, B. (2017). Advance philosophy of education. Chennai, Tamil Nadu: Notion Press.

Chism, N.V. N. (1998). Developing a philosophy of teaching statement. Essays on Teaching Excellence, 9(3), I-2. A publication of the Professional and Organizational Development Network in Higher Education. Retrieved from http://ucat.osu.edu/wordpress/ assets/V9-N3-Chism.pdf

Cooperrider, D., \& Whitney, D. (2005). Appreciative inquiry: A positive revolution in change. In P. Holman, T. Devane \& S. Cady (Eds.), The change handbook: The definitive resource on today's best methods for engaging whole systems (I st ed., 73-88). Francisco, CA: Berrett-Koehler.

Durie, M. (1998). Whaiora: Maori health development. Auckland, NZ: Oxford University Press.

Elen, J., Clarebout, G., Leonard, R., \& Lowyck, J. (2007). Student-centred and teacher-centred learning environments: What students think. Teaching in Higher Education, $12(1), 105-117$.

Jarvis, P. (20।0). Adult education and lifelong learning (4th ed.). New York, NY: Routledge.

Kamardeen, I. (2015). Critically reflective pedagogical model: A pragmatic blueprint for enhancing learning and teaching in construction disciplines. Construction Economics and Building, 15(4), 63-75.

Knowles, M. S., Holton, E., Holten, E. F. \& Swanson, R. A. (1998). The adult learner: the definitive classic in adult education and human resource development. Houston, TX: Gulf Publishing Company.

Kolb, D. A. (1984). Experiential Learning: Experience as the Source of Learning and Development. Englewood Cliffs, NJ: Prentice Hall. Retrieved from: http://academic.regis.edu/ed205/Kolb.pdf

Kolb, D. A. (2015). Experiential learning: Experience as the source of learning and development. Upper Saddle River, NJ: Pearson Education Inc. 
Mang, P. and Reed, B. (2012). Regenerative Development and Design. Chapter 303, Encyclopaedia Sustainability Science \& Technology, 2nd Edition. Retrieved from https://www.researchgate.net/profile/Pamela_Mang/publication/321 I56684_ Update_Regenerative_Development_and_Design_2nd_edition/links/5a I la93 I 0f7e9bd I b2c0bc9c/Update-RegenerativeDevelopment-and-Design-2nd-edition.pdf

Maslow, A. H. (1943). A theory of human motivation. Psychological Review, 50(4), 370-396.

Maslow, A. H. (1954). Motivation and personality. New York: Harper and Row.

Ministry of Education (1999). Health and Physical Education in the New Zealand Curriculum. Wellington, NZ: Learning Media.

Ministry of Health $(201 \mathrm{l})$. Māori health models - Te Whare Tapa Whā. Retrieved from https://www.health.govt.nz/our-work/ populations/maori-health/maori-health-models/maori-health-models-te-whare-tapa-wha

Moon, J. (2004). A handbook of reflective and experiential learning. London, UK: Routledge Falmer.

Nistor,V. M., \& Samarasinghe, D. A. S. (2019). Academic staff induction and assessment on implementing experiential learning and reflective practice. IAFOR Journal of Education, 7(2), |49-167.

Reed, B. (20I4). The Regenerative Practitioner ${ }^{\mathrm{TM}}$ video transcript:Three lines of work. Retrieved from http://www.regenesisgroup.com/ wp-content/uploads/2015/03/Three_Lines_of_Work.pdf

Roberts, T. G. (2006). A philosophical examination of experiential learning theory for agricultural education. Journal of Agricultural Education, 47(I), I7-29.

Rolfe, G., Freshwater, D., \& Jasper, M. (200I). Critical reflection in nursing and the helping professions: A user's guide. Basingstoke, UK: Palgrave Macmillan.

Samarasinghe, D. A. S. (2019). A reflection of an effective assessment practice in the Bachelor of Construction programme: An experiential learning case study in New Zealand. Scope: Contemporary Research Topics (Flexible Learning), 5, 48-53.

Samarasinghe, D. A. S., Abd-Latif, S., \& Baghaei, N. (20 I 9). Virtual reality models for promoting learner engagement in construction studies. Paper presented at the EDUCON2019 - IEEE Global Engineering Education Conference, Dubai, UAE.

Schönwetter, D. J., Sokal, L., Friesen, M., \& Taylor, K. L. (2002). Teaching philosophies reconsidered: A conceptual model for the development and evaluation of teaching philosophy statements. International Journal for Academic Development, 7(I), 83-97. http://dx.doi.org/10.1080/1360144021015650 |

Thorpe, M. (2000). Encouraging students to reflect as part of the assignment process: Student responses and tutor feedback. Active Learning in Higher Education, I ( I), 79-92.

Woodward, D., Hegarty, B., Allen, E., \& Redfearn, S. (2018). Developing a teaching philosophy. Paper presented at Capable NZ Professional Practice Symposium: Exploring Professional Futures, II December 20 I8, Otago Polytechnic.

Woodward, D., Wakelin, K., Booth, S., \& Redfearn, S. (2019a). Developing a teaching philosophy for a teaching credential: Enablers, challenges and use of metaphor. Paper presented at Capable NZ Praxis Symposium, I I December 20 I9, Otago Polytechnic.

Woodward, D., Hegarty, B., Allen, E., Booth, S., Redfearn, S., Smith, S., Wakelin, K., \& Webster, J. (20I9b). Developing a teaching philosophy for a teaching credential. Scope: Contemporary Research Topics (Learning and Teaching), 7, 31-42. https://doi. org/10.34074/scop.4007005.

Vygotsky, L. (1978). Mind in society. Cambridge, MA: Harvard University Press. 